\title{
Analysis Effect on Readiness to the Implementation of Performance Based Contract (PBC) in PT Pelabuhan Indonesia III (Persero)
}

\author{
Angga Tri Wibowo and I Putu Artama Wiguna \\ Department of Technology Management, Institut Teknologi Sepuluh Nopember, Surabaya \\ e-mail: artama.wiguna@gmail.com
}

\begin{abstract}
The type of contract for the road project used in PT Pelabuhan Indonesia III (Persero) is currently using the type of General Contracting. The contract is conventional and is considered to have many weaknesses. To obtain more optimal project results and maintenance can run optimally, in addition to improving quality control by the project supervisory team, one way that can be done is to change the use of innovative types of contracts. namely Performance Based Contracts (PBC). When implementing the PBC for the first time, there are several things that must be prepared, one of which is the readiness of the owner and contractor. Analysis in this study uses Structural Equation Modeling (SEM). The results obtained are that the variable readiness to use $\mathrm{PBC}$ has a positive effect on the application of PBC. If the readiness variable increases by one unit and the other variables are considered constant then the PBC implementation variable will increase by 0.390 .
\end{abstract}

Keywords-Conventional Contracts, Performance Based Contract, SEM.

\section{INTRODUCTION}

A $\mathrm{T}$ present the type of procurement commonly used in road construction projects at PT Pelabuhan Indonesia III (Persero) still separates the design, construction and maintenance phases, which are referred to as general contracting. The general contracting contract uses a unit price system and requires certain technical specifications that must be used by the contractor and falls into the conventional contract type category. In the contract, the contractor is only obliged to carry out the construction phase, where the period of responsibility for the implementation of the work is during physical implementation and a maintenance period of several months. If after the handover of the work results in construction damage, the maintenance is the responsibility of PT Pelabuhan Indonesia III (Persero). Road maintenance activities are now considered ineffective with several obstacles, namely damage repair is usually done shortly when damage occurs, limited costs for maintenance activities, the large amount of human resources that must be allocated for planning and supervision, requires a long time starting from damage inspection, planning and repairs, and cannot guarantee the quality of the results of repairs. To obtain more optimal project results and maintenance can run optimally, in addition to improving quality control by the project supervisory team, one way that can be done is to change the use of innovative types of contracts. namely Performance Based Contract (PBC). Performance Based Contract (PBC) is a type of contract that has its own characteristics, namely integrated planning and implementation in a contract carried out by a service provider and implemented in multi-years and payments are made using a lump sum system. In PBC there is integration of all stages of design, construction and maintenance. With this type of contract, contractors can make technological innovations to get the most efficient construction and maintenance costs. PBC contracts allocate higher risk to contractors than conventional contracts, but at the same time open up opportunities to increase their margins where increased efficiency and effectiveness of design, process technology, or management can reduce costs to achieve established work standards [1].

Conventional contract types and Performance Based Contracts (PBC) have several differences when reviewed in each stage of the construction activity implementation activities, namely: at the planning stage, the procurement stage, the implementation stage, and the maintenance stage. At the planning stage in conventional contracts, the basis for contract preparation is the input (resources and implementation methods used) needed for the service user goal to be achieved, whereas for PBC the basis for contract preparation is the final outcome desired by the service user. At the procurement stage, in conventional contracts the specifications used are prescriptive specifications while in PBC the specifications are output oriented. In addition to conventional contracts, contracts are used for annual and long-term contracts while PBC is appropriate for long-term contracts. In conventional contracts the evaluation of bids is based on the lowest bidder, while the PBC is based on the best value. At the implementation stage, the conventional contract payment to the contractor is based on the volume of work completed, while the PBC is based on performance that meets performance standards and the assessment of work is not based on the volume of work completed, but based on the performance of services that have been achieved. Whereas if there is a deduction of payment, in a conventional contract the payment is deducted if the work does not meet the specifications, whereas in PBC the payment is deducted if the work results do not meet the established performance standards. In a conventional contract the contractor's performance monitoring system is carried out by the owner through a supervisory consultant, whereas in PBC the supervision is fully delegated to the contractor. At the maintenance stage, in a conventional contract the contractor is not responsible for maintenance after the project is completed, whereas in PBC which is a long-term contract, the 
The $6^{\text {th }}$ International Seminar on Science and Technology (ISST) 2020

July $25^{\text {th }} 2020$, Institut Teknologi Sepuluh Nopember, Surabaya, Indonesia

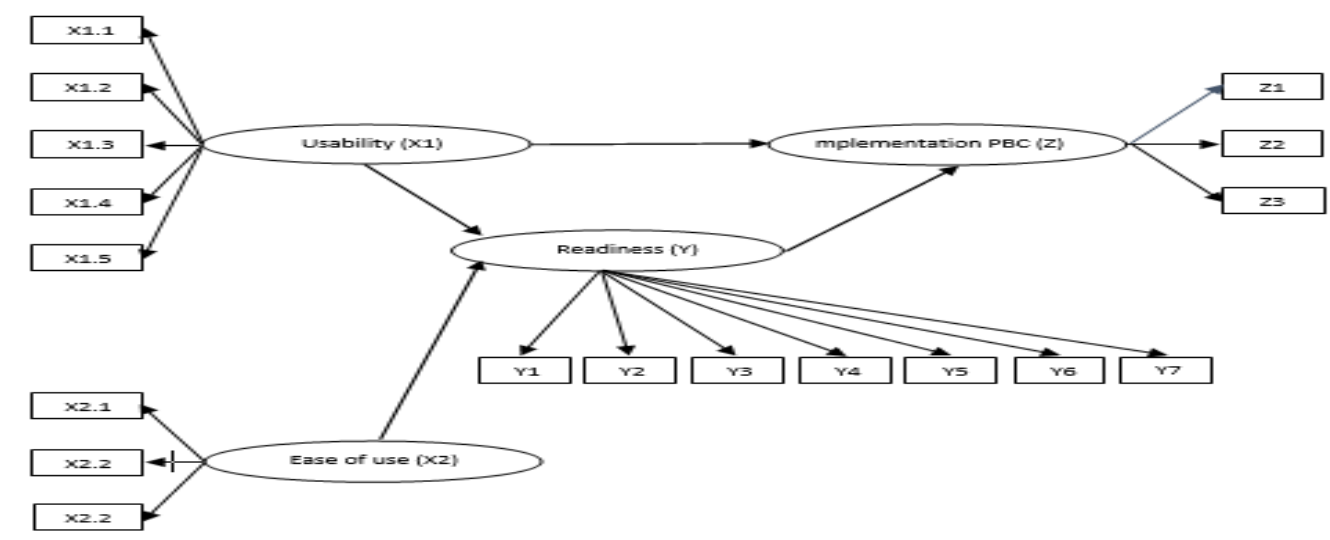

Figure 1. Path Diagram.

Table 1.

Laten Eksogen Variable

\begin{tabular}{ccl}
\hline \hline Laten Exogen Variable & & \multicolumn{1}{c}{ Indicator } \\
\hline & X1.1 & certainty of long-term road performance \\
X1.2 & road maintenance is more timely \\
Usability & X1.3 & cost savings for managing and maintaining roads in the long run, ranging from 10\% - 40\% \\
& X1.4 & provide certainty of long-term maintenance financing and funding needs \\
& X1.5 & reduce the risk for the owner because most of the risk has been shifted to the contractor \\
Ease of use & X2.1 & makes it easy to manage roads with fewer staff \\
& X2.2 & facilitate the making of planning and programming financing \\
& X2.3 & make it easy for contractors to make technological innovations and increase productivity \\
Y1 & there are regulations governing the implementation of the PBC \\
& Y3 & the owner is able to provide sufficient budget because of the long-term work contract \\
Readiness & the owner is able to determine performance indicators, how to measure them, and a grace period to correct any \\
& Y4 & non-conformities in implementation \\
& Y5 & the owner is able to provide human resources who understand the implementation of work with PBC \\
& Y6 & the contractor has adequate equipment to carry out work with the PBC \\
Y7 & the contractor has sufficient funding to carry out work with PBC in the long term \\
\hline \hline
\end{tabular}

Table 2.

Laten Endogen Variable

\begin{tabular}{ccl}
\hline \hline Laten Endogen Variable & & \multicolumn{1}{c}{ Indicator } \\
\hline & $\mathrm{Z} 1$ & the implementation of work is more effective and efficient \\
Implementation PBC & $\mathrm{Z} 2$ & savings are obtained for road maintenance \\
& $\mathrm{Z} 3$ & good and safe road infrastructure is obtained \\
\hline \hline
\end{tabular}

contractor is the party responsible for maintenance. Judging from the differences, starting from the planning, procurement, implementation and maintenance stages, the use of PBC contract types will be more effective when applied to road projects.

The development of PBC for road maintenance began in the late 1980s and early 1990s. PBC was initiated by British Columbia in Canada who contracted road maintenance in 1988 , but the performance standards used were still oriented to work procedures and materials used and not oriented towards the final result. This standard severely limits contractors from innovating technology. Australia first used a performance contract in 1995 covering 459 city streets in Sydney. After that several new contracts have been applied in New South Wales, Tasmania, Western and Southern Australia. In 1998 New Zealand implemented a performance contract for $406 \mathrm{~km}$ of national roads. A study shows that some countries that have implemented PBC have achieved some success as follows: cost savings from $10 \%$ to $40 \%$, Certainty of expenditure, reduction of labor in the office [2].

In Indonesia the first PBC implementation was initiated by PT. Jasa Marga (Persero), in 2000 tried to implement a Performance Based Maintenance Contract (PBMC) for the
Cawang-Pluit toll road, the background of implementing this PBMC was because PT Jasa Marga (Persero) wanted the sustainability of the level of road services during service period Previously the contract used was a conventional contract so that PT Jasa Marga experienced several obstacles such as the number of contracts that had to be handled every year, the large amount of human resources that must be allocated for planning and supervising work, damage repair is usually done just before the final hand over (Final Hand Over), there is no penalty if damage occurs during the maintenance period.

This research was conducted with the aim to determine the effect of the readiness of the work owner and contractor in the implementation of PBC and the relationship of factors in readiness that affect the implementation of PBC in PT Pelabuhan Indonesia III (Persero) using Structural Equation Modeling (SEM).

\section{METHOD}

This research was conducted with a quantitative method which is a study using statistical analysis of empirical study approaches using Structural Equation Modeling (SEM) and 
The $6^{\text {th }}$ International Seminar on Science and Technology (ISST) 2020

July $25^{\text {th }} 2020$, Institut Teknologi Sepuluh Nopember, Surabaya, Indonesia

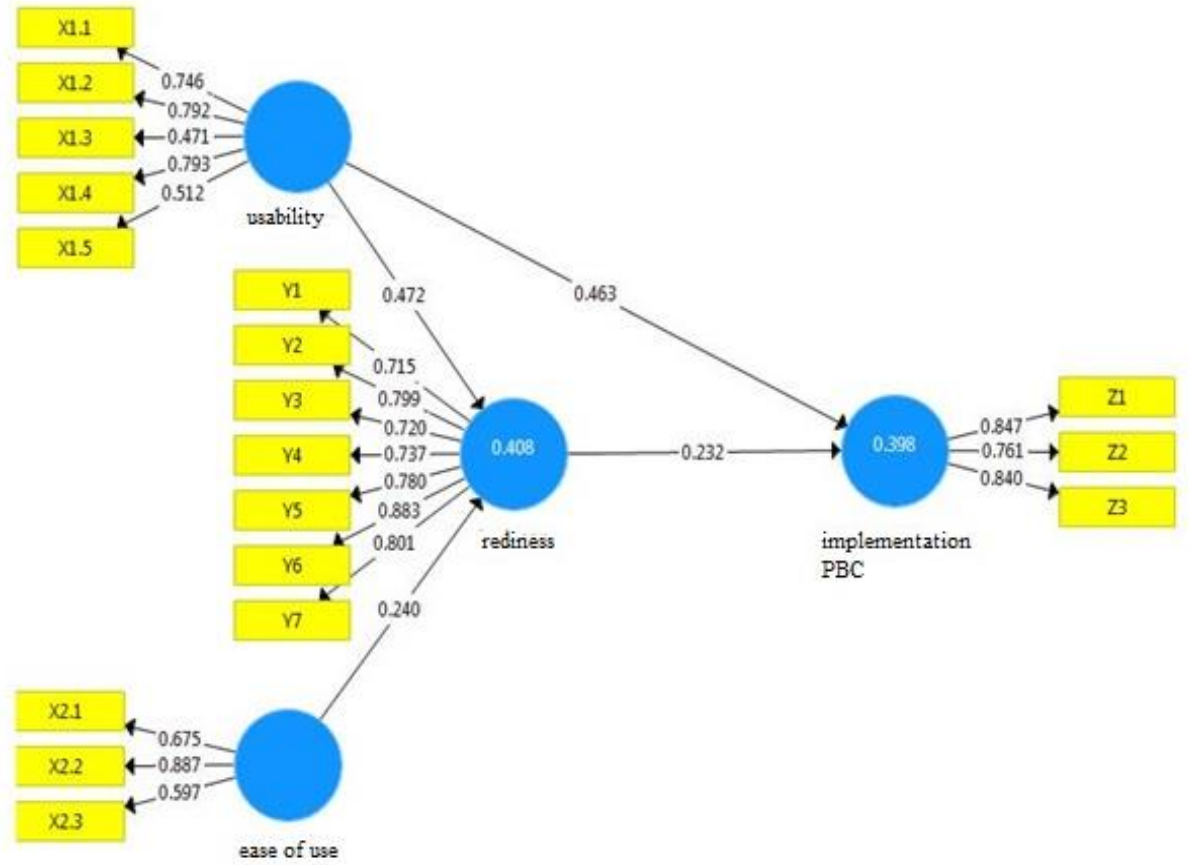

Figure 2. Path Diagram of The Equation.

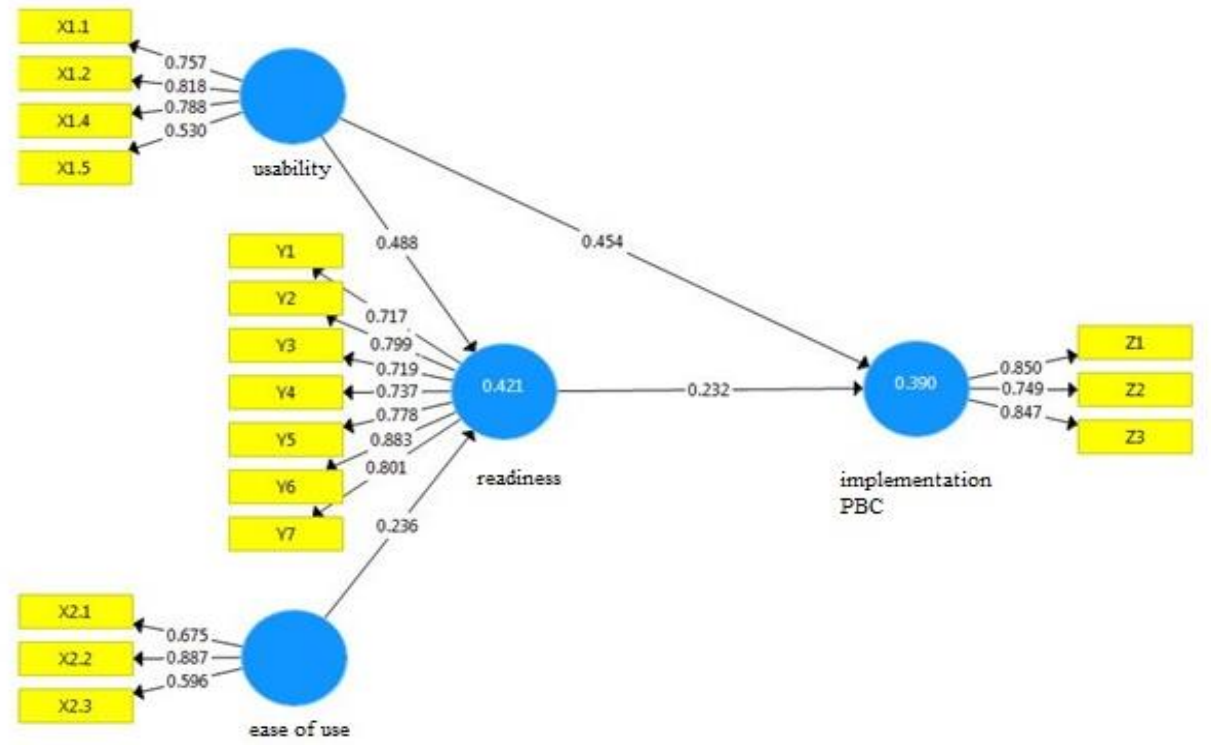

Figure 3. Path Diagram of The Equation Step 2.

Technology Acceptance Model (TAM) to achieve, analyze and show data processing in numerical form and carried out for certain samples or populations and using. Secondary data were obtained from the literature while primary data were obtained from questionnaires filled out by 90 respondents.The final results of this study are numerical and are summarized and explained in the narrative. The variables in this study were obtained from the literature which was then adjusted to the purpose of the study. The variable used is the Exogen Variable which is usability, ease of use and readiness, Endogen Variables which the implementation PBC.

\section{A. Determining Variable and Indicator of Research}

The variables in this study were obtained from the literature adjusted to the usefulness and ease of PBC. The used variable consists of Exogen Variables, namely Usability, Ease of use and Readiness, while the endogen Variables is implementation of PBC. Laten eksogen variable and laten endoden variable can see in Table 1 and Table 2, respectively. Figure 1 show the path diagram.

\section{B. Result}

\section{1) Evaluation Outer Model}

Measurement model evaluation is used to understand the connection between laten variable with its indicators. The evaluation are validity assessment and reliability to recognize if indicators used are valid and reliable in defining laten variable.

Validity tests can be done using convergent validity by observing the value of loading factor. Loading factor is value 
The $6^{\text {th }}$ International Seminar on Science and Technology (ISST) 2020

July $25^{\text {th }} 2020$, Institut Teknologi Sepuluh Nopember, Surabaya, Indonesia

Table 3.

Step 1 of Loading Factor Value of Each Indicator

\begin{tabular}{ccc}
\hline \hline Laten Endogen Variable & Indicator & Loading Factor \\
\hline & $\mathrm{X} 1.1$ & 0,746 \\
Usability & $\mathrm{X} 1.2$ & 0,792 \\
& $\mathrm{X} 1.3$ & 0,471 \\
& $\mathrm{X} 1.4$ & 0,793 \\
& $\mathrm{X} 1.5$ & 0,512 \\
Ease of use & $\mathrm{X} 2.1$ & 0,675 \\
& $\mathrm{X} 2.2$ & 0,887 \\
& $\mathrm{X} 2.3$ & 0,597 \\
& $\mathrm{Y} 1$ & 0,715 \\
& $\mathrm{Y} 2$ & 0,799 \\
Readiness & $\mathrm{Y} 3$ & 0,720 \\
& $\mathrm{Y} 4$ & 0,737 \\
& $\mathrm{Y} 5$ & 0,780 \\
& $\mathrm{Y} 6$ & 0,883 \\
& $\mathrm{Y} 7$ & 0,801 \\
& $\mathrm{Z} 1$ & 0,847 \\
\hline \hline
\end{tabular}

Table 4.

Step 2 of Loading Factor Value of Each Indicator

\begin{tabular}{ccc}
\hline \hline Laten Variable & Indicator & Loading Factor \\
\hline \multirow{3}{*}{ Usability } & X1.1 & 0,757 \\
& X1.2 & 0,818 \\
& X1.4 & 0,788 \\
Ease of use & X1.5 & 0,530 \\
& X2.1 & 0,875 \\
& X2.2 & 0,599 \\
& X2.3 & 0,717 \\
Readiness & Y1 & 0,799 \\
& Y2 & 0,719 \\
& Y3 & 0,737 \\
& Y4 & 0,778 \\
Implementation PBC & Y5 & 0,883 \\
& Y6 & 0,801 \\
\hline \hline
\end{tabular}

Table 5.

Reliability Test Results

\begin{tabular}{ccc}
\hline \hline Laten Variable & Cronbach's Alpha & Composite Reliability \\
\hline Usability & 0,713 & 0,818 \\
Ease of use & 0,676 & 0,769 \\
Readiness & 0,890 & 0,915 \\
Implementation PBC & 0,750 & 0,857 \\
\hline \hline
\end{tabular}

of correlation between laten variable with each indicators' variable. The loading factor value can be determined valid if has value of $\geq 0,5$. If there are indicators with loading factor value of $<0,5$, those indicators are taken out from the model. Figure 2 below is Lane Equation Structural diagram between laten variables affecting project performance based on bidding process, and accommodate coefficient of loading factor in each indicator lane with its laten variable.

Result of the correlation value between laten variable with each of its indicators used for validity testing, is summarized in Table 3. Based on the Table 3, there are invalid indicators in the latent variable of the bidding process, X1.3 because the loading factor is $<0.5$. Invalid indicators are excluded from the model.

Loading factor value between laten variable with indicator on Figure 3 which counted based on data can be seen in Table 4. Based on Table 4, can be seen that after the invalid variable is taken out from the model, all value of the loading factor in each indicators from five laten variables are valued $\geq 0,5$, therefore can be concluded that the convergent validity of each indicator variable is indicated valid in measuring the laten variable because the loading factor is achieved.

Reliability test can be seen using composite reliability. The reliability test aimed to see if the indicators are reliable in measuring laten variable. The reliability can be measured with the value of cronbach's alpha and composite reliability. Indicators can be said reliable when achieve the value of cronbach's alpha is $\geq 0,5$ and composite reliability is $\geq 0,7$.

Table 5 shows the value of cronbach's alpha and composite reliability from each laten variable of usability, ease of use, readiness and implementation PBC. The value of cronbach's alpha from four laten variables showed value more than 0,5 . Whereas the composite reliability value from four laten variables are more than 0,7 . This shows that each indicator variable is reliable in measuring its laten variable. 
The $6^{\text {th }}$ International Seminar on Science and Technology (ISST) 2020

July $25^{\text {th }} 2020$, Institut Teknologi Sepuluh Nopember, Surabaya, Indonesia

Table 6.

Result of Hypothesis Testing on Measurement Model

\begin{tabular}{|c|c|c|c|}
\hline Laten Variable & Indicator & Loading Factor & T-statistic \\
\hline \multirow{4}{*}{ Usability } & $\mathrm{X} 1.1$ & 0,757 & 13,699 \\
\hline & $\mathrm{X} 1.2$ & 0,818 & 17,786 \\
\hline & $\mathrm{X} 1.4$ & 0,788 & 13,963 \\
\hline & $\mathrm{X} 1.5$ & 0,530 & 4,346 \\
\hline \multirow{4}{*}{ Ease of use } & $\mathrm{X} 2.1$ & 0,675 & 5,513 \\
\hline & $\mathrm{X} 2.2$ & 0,887 & 25,808 \\
\hline & $\mathrm{X} 2.3$ & 0,599 & 4,214 \\
\hline & $\mathrm{Y} 1$ & 0,717 & 10,919 \\
\hline \multirow{4}{*}{ Readiness } & $\mathrm{Y} 2$ & 0,799 & 18,188 \\
\hline & Y3 & 0,719 & 9,942 \\
\hline & Y4 & 0,737 & 10,308 \\
\hline & Y5 & 0,778 & 12,932 \\
\hline \multirow{5}{*}{ Implementation PBC } & Y6 & 0,883 & 40,837 \\
\hline & Y7 & 0,801 & 19,992 \\
\hline & $\mathrm{Z} 1$ & 0,80 & 23,396 \\
\hline & $\mathrm{Z} 2$ & 0,749 & 7,417 \\
\hline & $\mathrm{Z3}$ & 0,847 & 21,101 \\
\hline \multicolumn{4}{|c|}{$\begin{array}{l}\text { Table } 7 . \\
\text { Results of Hypothesis Testing on Structural Model }\end{array}$} \\
\hline & Original Sample & T-statistic \\
\hline \multicolumn{2}{|r|}{$\begin{array}{c}\text { Laten Variable } \\
\text { Readiness }\end{array}$} & 0,488 & 4,591 \\
\hline Ease of use & $\begin{array}{l}\text { Readiness } \\
\text { Readiness }\end{array}$ & 0,236 & 2,231 \\
\hline Usability & Implementation PBC & 0,454 & 4,677 \\
\hline Readiness & Implementation PBC & 0,232 & 2,032 \\
\hline
\end{tabular}

\section{2) Evaluation Inner Model}

Once the evaluation of measurement model is valid and reliable, the next step is to evaluate the structural model (inner model). The evaluation of structural model (inner model) is used to evaluate the connection between laten variables. Measuring tools used to evaluate the structural model in this research are $R$-square (R2) dan $Q$-square Predictive Relevance (Q2) values. The R2 value shows capability of laten exogen variable to explain the variety in exogen variable. Based on software output, the $\mathrm{R} 2$ value in the laten endogen variable of implementation PBC is $39 \%$. This means that the variety of implementation PBC can be explained for $39 \%$ by laten variable of usability and readiness, while the $61 \%$ explained by other variable outside the model.

The value of $Q$-Square Predictive Relevance (Q2) used to validate the prediction ability on the model. If the $\mathrm{Q} 2$ value close to value of 1 , therefore can be said that the structural model has relevance prediction. Based on calculation result using data in attachment 3, obtained the value of Q2 is 0,39 . This value is more than 0 which means that the result of effect on readiness to the implementation PBC with PLS has high predictive revelance.

\section{3) Hypothesis Testing}

The Hypothesis testing (resampling bootstrap) is used to show level of parameter significance from indicator variable in measurement model (outer model) and in structural model (inner model). Hypothesis testing in PLS encompasses testing to parameters of $\lambda, \beta$, and $\gamma$. Statistic test used is t-statistics or t-tests.

\section{4) Hypothesis Outer Model}

The parameter significance of outer model can be evaluated through resampling bootstrap procedure. The hypothesis used is as follows: $H 0: \lambda i=0$. Significance level of $\alpha$ used is $5 \%$, so that the t-table value is 1,987 .

Based on Table 6 , can be seen that the loading factor value of each indicator variable has worth $\geq 0,5$, and the t-statistics value from each indicator variable worth more than the t-table $=1,987$. This means that all indicator variables used are valid and significant, therefore those indicators can be used as measurement from the laten variable.

\section{5) Hypothesis Testing on Measurement Model (Inner Model)}

Once the hypothesis testing is done on the measurement model, next is perform the hypothesis testing on the structural model. The parameter significance of inner model can be evaluated through resampling bootstrap procedure. The hypothesis used is as follows:

a. Laten variable of usability to laten variable of readiness $H 0: \lambda 11=0$

b. Laten variable of ease of use to laten variable of readiness $H 0: \lambda 21=0$

c. Laten variable of usability to laten variable of implementation PBC

$H 0: \lambda 31=0$

d. Laten variable of readiness to laten variable of implementation PBC

$H 0: \lambda 41=0$

Significance level of $\alpha$ used is $5 \%$, so that the t-table value is 1,987. Table 7 is t-statistics testing result on structural model (inner model). The t-statistics value is counted based on data. Table 7 showed that t-statistics value from laten variable of readiness to implementation PBC is worth of 2,032, which is higher than the t-table which is 1,987 . Therefore can be concluded that the effect is significant, or the readiness has positive influence to implementation PBC and its worth of 0,232 . 
The $6^{\text {th }}$ International Seminar on Science and Technology (ISST) 2020

July $25^{\text {th }} 2020$, Institut Teknologi Sepuluh Nopember, Surabaya, Indonesia

\section{CONCLUSION}

Conclusions from analysis and study on the effect of laten eksogen variable of PBC implementation readiness on laten endogen variable of implementation PBC using Structural Equation Modeling Partial Least Square (SEM-PLS) are as follows: (1)Variable of PBC implementation readiness has a significant effect on the variable of implementation PBC. If the variable of $\mathrm{PBC}$ implementation readiness increases by one unit and the other variables are considered constant then the variable of implementation PBC will increase by 0,390 ; (2)All indicator variables on the PBC implementation readiness variable have a positive effect. The most of effect indicator is that the contractor has HR who understands the implementation of work with the PBC system with a loading factor of 0,883 .

\section{REFERENCES}

[1] Gunter Zietlow, Cutting Costs and Improving Quality Though Performance-Based Road Management dan Maintenance Contract The Latin American and OECD Experiences. 2007.

[2] Stankevich, Natalya, Qureshi, Navaid and Queiroz, Cesar, "Roads and Rural Transport Thematic Group." Performance-based Contracting for Preservation and Improvement of Road Assets. The World Bank, Washington DC, 2005. 